\title{
ANALISIS MATERI ASTRONOMI PADA PEMBELAJARAN SAINS (PENYAJIAN SAINS MODERN DAN ALQURAN)
}

\author{
Esti Yuli Widayanti \\ (Dosen STAIN Ponorogo)
}

\begin{abstract}
Abstrak
Menyandingkan sains dengan al-Quran dalam pembelajaran sudah banyak diperbincangkan, namun masih belum banyak dipraktikkan di pembelajaran sains sendiri, meskipun di sekolah berlabel agama. Hal ini disebabkan karena belum ada panduan khusus yang menyandingkan dua hal ini secara teknis. Buku-buku pelajaran masih memaparkan konsep secara ilmiah, sehingga yang disampaiakan guru juga hanya apa yang ada di dalam buku, yang kebetulan mereka jadikan acuan. Tujuan studi ini adalah memberikan sebuah acuan bagi para guru kelas di SD/MI dalam membelajarkan materi sains/IPA (meliputi fakta, konsep, prinsip, hukum, dan teori IPA) yang didukung dengan penyampaian ayat-al-Quran dan tafsitnya yang berkaitan dengan materi tersebut. Salah satu materi sains yang sangat menantang dan mengalami perkembangan yang signifikan dari masa ke masa adalah materi astronomi.

Studi ini merupakan kajian kualitatif yang bertujuan menggambarkan dan mengungkap sebuah fenomena dalam hal penyampaian materi astronomi di SD/MI. Fenomena menarik disini berkaitan dengan bagaimana guru sains menyampaikan materi astronomi dengan yang dikuatkan dengan penyampaian ayat-ayat al-Qur'an serta tafsirnya yang terkait dengan materi astronomi SD/MI. Semakin terbuktinya ilmu astronomi yang diungkap di ayat-ayat al-Quran oleh hasil penelitian ilmiah, maka penyampaian ayat-ayat al-Qur'an bersamaan dengan materi sains adalah hal yang sangat penting.

Hasil kajian meliputi tiga hal. Kajian pertama adalah analisis produk sains meliputi fakta, konsep, prinsip, hukum, dan teori. Untuk materi astronomi berdasarkan kurikulum 2006, diajarkan di kelas I, II, dan VI. Sedangkan berdasarkan kurikulum 2013, materi sains/IPA terkait astronomi disampaikan secara khusus di kelas VI. Kajian kedua mengidentifikasi ayat al-quran terkait dengan materi astronomi disesuaikan dengan ruang lingkup
\end{abstract}


materi di SD/MI. Analisis terakhir yaitu strategi penyampaian ayat-al-Qur'an sebagai penguat materi astronomi adalah model terpadu dengan direct instruction.

Kata Kunci: Materi Astronomi, Ayat-Tafsir Al-Quran tentang Astronomi, dan Strategi Penyampaian Ayat Al-Quran.

\section{A. Pendahuluan}

Dalam menghadapi arus materialisme yang meminggirkan unsurunsur keagamaan dan kerokhanian, sistem pendidikan di Indonesia hendaknya dapat mengambil sebuah langkah konkrit agar masyarakat tidak semakin terseret arus globalisasi. Salah satu cara yang telah dilakukan pemerintah adalah dengan mengubah kurikulum pendidikan dasar dan menengah yang berbasis karakter baik pada kurikulum 2006 yang berbasis karakter maupun kurikulum 2013, yang sudah terintegrasi karakter.

Pada kurikulum berbasis karakter baik kurikulum 2006 maupun 2013, lulusan hendaknya dapat mencapai standar kelulusan yang mencapai kompetensi sesuai dengan indikator nilai karakter. Tahun 2006 yang berbasis karakter, mengindikasikannya dengan 18 nilai karakter, sedangkan untuk kurikulum 2013 mengindikasikannya pada pemenuhan standar kompetensi lulusan degan pencapaian kompetensi inti yaitu pada dimensi sikap spiritual dan sikap sosial.

Dengan semakin terbukanya kesempatan penintegrasian nilainilai spiritual pada mata pelajaran umum, maka guru semakin mudah merancang pembelajaran karena mempunyai acuan yang jelas. Salah satu cara mengintegrasikan nilai sikap spiritual pada mata pelajaran adalah dengan memberikan pemikiran sesuai dengan ilmu yang ada dalam A1Quran. Salah satu ilmu yang banyak terkandung dalam al-Qur'an adalah ilmu sains, misalnya saja meliputi bidang astronomi, fisika, geologi/bumi, dan kedokteran. ${ }^{1}$

1 Zakir Na'ik, The Qur'an and Modern Science; Compatibel or Incompatible (Riyadh: Dar-US-Salaam, 2007) 
Menyandingkan sains dengan alquran dalam pembelajaran sudah banyak diperbincangkan, namun masih belum banyak dipraktikkan di pembelajaran sains sendiri, meskipun di sekolah yang berlabel agama (sekolah Islam atau madrasah). Hal ini disebabkan karena belum ada panduan khusus yang menyandingkan dua hal ini secara teknis. Bukubuku pelajaran masih memaparkan konsep secara ilmiah, sehingga yang disampaiakan guru juga hanya apa yang ada di dalam buku, yang kebetualan mereka jadikan acuan. Dalam rencana pembelajaranpun masih terbatas pada tujuan pembelajaran sains secara umum, belum pada aspek memahamkan siswa untuk mengetahui konsep sains dari pandangan Islam (Al-quran dan hadist).

Berdasarkan latar belakang inilah, penulis melakukan studi dengan menganalisis materi bumi dan alam semesta, terutama topik antariksa. Topik ini menarik mengingat ilmu pengetahuan tentang antariksa mengalami perkembangan yang signifikan dari waktu ke waktu seiring ditemukannya teknologi pendukung untuk melakukan pengamatan. Ilmu Al-Quran yang sudah disampaikan lebih dari 14 abad yang lalu dapat disandingkan dengan ilmu pengetahuan tentang alam semesta selalu mengalami perkembangan tersebut.

Secara lebih spesifik, tujuan dari studi ini adalah: 1) mendeskripsikan fakta, konsep, hukum dan teori tentang materi bumi dan alam semesta, yang berkaitan dengan bumi dan antariksa, dari kelas I sampai kelas VI SD/MI; 2) mengidentifikasi ayat al-Quran dan tafsirnya yang berhubungan dengan materi pada point (1);3) menganalisis strategi penyampaian ayat al-Quran dalam pembelajaran sains $\mathrm{SD} / \mathrm{MI}$.

\section{B. Astronomi dan Tafsir Al-Quran}

Al-Quran sebagai kitab suci yang berlaku untuk semua zaman dan tempat melalui tafsirnya perlu selalu ditampilkan sebagai kitab petunjuk yang selalu dirasakan actual, segar, dan up to date. Ini dimaksudkan agar Al-Quran tidak kehilangan universitalitasnya sehingga mampu berbicara dan memberikan solusi dalam menjawab berbagai problem kehidupan manusia sepanjang zaman. ${ }^{2}$

2 Nanang Gojali, Manusia, Pendidikan, dan Sains dalam Perspektif Tafsir Hermeneutic (Jakarta: Rineka Cipta, 2004), 2. 
Kebenaran ilmiah telah terungkap di dalam Al-Quran lebih dari 1500 tahun sebelum terjadinya penemuan yang membuktikan secara mengesankan terhadap al-Quran dan keotentikannya sebagai wahyu Allah. Mengungkapan kebenaran ilmiah ini meliputi semua aspek dalam sains, yaitu: astronomi, biologi, medis, bumi dan lingkungan.

Menurut kesimpulan beberapa pemikir, Al-Quran sebagai kitab suci agama Islam mempunyai hubungan langsung dengan sains dan materi ilmiah, meskipun banyak pula pihak yang menentang. ${ }^{3}$ Dalam alQur'an sendiri, banyak ayat-ayat yang memberitahukan pentingnya sains dan menuntut ilmu, yang semakin meningkatkan ketertarikan para muslim untuk belajar. Selain menuntut para muslim untuk selalu belajar, ayat-ayat al-Quran juga berisi ilmu pengetahuan itu sendiri. Al-Qur'an bukanlah buku sains, tetapi buku yang berisi tanda-tanda dalam ayatayatnya. Terdapat lebih dari 6 ribu tanda dalam al-Qur'an yang berisis lebih dari seribu hal yang berkaitan dengan inti dari sains. ${ }^{4}$ Salah satu kajian sains yang fenomenal yang terdapat dalam Al-Quran adalah kajian tentang Bumi dan antariksa dimulai dari proses terbentuknya alam semesta serta fakta-fakta antariksa (benda-benda langit) yang terungkap sedikit demi sedikit oleh ilmu manusia (yang bagi manusia merupakan penemuan yang sangat fenomenal dengan didukung oleh teknologi yang tercanggih).

\section{Pembelajaran Ayat Al-Quran}

Membelajarkan Al-Qur'an yang terintegrasi pada mata pelajaran umum mempunyai persamaan dan perbedaan dengan membelajarkan A1Qur'an pada mata pelajaran Qur'an Hadist (di Madrasah Ibtidaiyah). Persamaannya, pembelajaran tetap menggunakan metode yang menarik, dengan tujuan agar siswa pada gilirannya mampu memahami kandungan Al-Qur'an dengan baik dan benar. Tujuan yang dirumuskan meliputi

\footnotetext{
${ }^{3}$ Mohd Yakub Zulkifli and Majid Daneshgar, Islam and the Relation of Science. Presnted paper on 2011 International Conference on Humanities, Society and Culture. IPEDR Vol.20 (2011). Siangapore: IACSIT Press, 53.

${ }^{4}$ Zakir Naik, The Qur'an and Modern Science; Compatibel or Incompatible.
} 
aspek pengetahuan (knowing), aspek pelaksanaan (doing), dan aspek pembiasaan (being). ${ }^{5}$

Dalam aspek pengetahuan, murid memiliki pengetahuan mengenai berbagai hal yang berkenaan dengan pemahaman kandungan Al-Qur'an dan hadits. Dengan demikian dibutuhkan kesabaran dan ketelatenan dari guru untuk mengarahkan dan mendidik siswanya. Karena pada aspek knowing ini guru harus benar-benar yakin bahwa semua murid telah mengetahui apa yang telah dipelajarinya. Untuk mencapai tujuan ini, guru dapat memilih metode ceramah, tanya jawab, dan demonstrasi.

Kedua adalah aspek pelaksanaan (doing). Dalam hal ini, pelaksanaan yang dimaksud adalah peserta didik terampil dalam memahami kandungan Al-Qur'an dan hadits, paling tidak yang menjadi materi pelajaran. Untuk mencapai tujuan ini metode yang dapat digunakan misalnya adalah demonstrasi atau simulasi. Misalnya ketika memberikan pembelajaran tentang memahami kandungan surat AdhDuha, guru dapat menyelenggarakan sebuah permainan sandiwara yang berkenaan dengan kandungan surat Adh-Dhuha. Setelah permainan selesai guru menjelaskan kandungan surat Adh-Dhuha sebagaimana yang diperagakan.

Ketiga adalah aspek Pembiasaan (Being). Keterampilan dalam memahami kandungan Al-Qur'an dan hadits itu tidak hanya sekedar untuk diketahui tetapi juga menjadi miliknya dan menyatu dengan kepribadiannya. Dalam contoh di atas, setelah siswa benar-benar terampil memahami kandungan Al-Qur'an dan hadits, maka setiap ia telah membaca Al-Qur'an dan hadits, atau mendengarkan bacaan Al-Qur'an atau hadits, maka ia mampu menyelami dan memahami kandungan dari bacaan Al-Qur'an atau hadits tersebut. Inilah tujuan pengajaran aspek being . Pembelajaran untuk mencapai being yang tinggi lebih mengarahkan pada usaha pendidikan agar murid melaksanakan apa yang diketahuinya itu dalam kehidupan sehari-hari. Untuk menjaga agar proses

5 Dirjen Diktis, Pembelajaran Al-Quran dan Hadis (Pembelajaran Memahami Kandungan Al-Qur'an dan Hadist) (Jakarta: Direktorat Jendral Pendidikan Islam, 2010). 
pemahaman siswa terhadap Al-Qur'an dan hadits tetap baik, maka perlu untuk melakukan pembiasaan.

\section{Model Pembelajaran Terpadu Ayat Al-Quran}

Agar tujuan pembelajaran al-Quran yang melekat pada konsepkonsep pengetahuan sains ilmiah dapat tercapai secara efektif dan maksimal, maka pembelajaran harus dilakukan dengan pola pembelajaran yang sistematis dengan mengikuti model, metode, pendekatan yang sesuai. Konsep-konsep yang terintegrasi, menurut beberapa ahli, memerlukan sebuah strategi yang berbeda dengan pembelajaran dengan konsep ilmu pengetahuan tunggal. Strategi yang digunakan adalah model pembelajran terpadu seperti yang disampaikan oleh Fogarty dan Imam Siregar. ${ }^{6}$

Menurut Fogarty, model terpadu terbagi menjadi tiga tipe. Tipe pertama, yaitu model pembelajaran terpadu Tipe Pertama, yaitu model pembelajaran terpadu dalam satu bidang studi (model Fragmented, Connected, dan Nested). Tipe kedua, yaitu model pembelajaran terpadu antar bidang studi (model Sequened, Shared, Webbed, Threaded, dan Integrated). Tipe ketiga, yaitu model pembelajaran terpadu dalam faktor diri siswa (model Immersed dan Networked).

Sedangkan model terpadu yang lain adalah: 1. Model Connected (model keterhubungan) adalah model pembelajaran terpadu yang secara sengaja diusahakan untuk menghubungkan satu konsep dengan konsep lain, satu topik dengan topik lain, satu keterampilan dengan keterampilan lain, tugas-tugas yang dilakukan sehari-hari dengan tugas-tugas berikutnya, di dalam satu bidang studi. 2. Model Webded (model jaringan laba-laba), model ini merupakan pembelajaran terpadu yang menggunakan pendekatan tematik. 3. Model Integrated (model keterpaduan), model ini merupakan pembelajaran terpadu yang menggunakan pendekatan antara bidang studi dengan menetapkan prioritas kurikuler dan menemukan keterampilan, konsep dan sikap yang saling tumpang tindih dalam beberapa bidang studi. Berbeda dengan model laba-laba yang menuntut pemilihan tema dan pengembangannya sebagai langkah awal, maka dalam model keterpaduan tema-tema yang

\footnotetext{
${ }^{6}$ Jamiludin. Integrasi Pendidikan Islami: Nilai-nilai Islami dalam Pembelajaran.
} 
saling terkait dan tumpang tindih merupakan hal terakhir yang ingin di cari dan dipilih guru dalam tahap perencanaan program.

\section{E. Analisis Materi Sains dan Ayat Al-Quran terkait Materi Astronomi}

Setelah menelaah Standar kompetensi dan kompetensi dasar mata pelajaran IPA tingkat sekolah dasar berdasarkan standar isi kurikulum 2006, maka materi bumi dan antariksa (astronomi) diajarkan di kelasI, II, dan VI. Materi yang dicakup meliputi: pengenalan benda-benda langit, terjadinya siang dan malam, posisi bulan, sistem tata surya, rotasi, revolusi, gerhana bulan dan matahari, serta perhitungan kalender masehi dan hijriyah.

Tabel 1 merupakan hasil analisis yang mengungkapakan materi terkait kajian tentang astronomi yang ada di sekolah dasar berdasarkan jenis produk sains (yaitu fakta, konsep, prinsip, hukum, dan teori) serta ayat-alquran yang terkait dengan materi tersebut.

Sedangkan materi astronomi pada kurikulum 2013 dibahasa di kelas VI pada Kompetensi Inti (3) Memahami pengetahuan faktual dan konseptual dengan cara mengamati dan mencoba (mendengar, melihat, membaca) serta menanya berdasarkan rasa ingin tahu secara kritis tentang dirinya, makhluk ciptaan Tuhan dan kegiatannya, dan benda-benda yang dijumpai di rumah, sekolah dan tempat bermain.

Kompetensi Dasar pada kompetensi inti tersebut yang melingkupi materi antariksa adalah: (3.1.) Mendeskripsikan sistem tata surya, matahari sebagai pusat tata surya, serta posisi serta karakteristik anggota tata surya; (3.2) Mendeskripsikan peristiwa rotasi bumi, revolusi bumi, revolusi bulan, dan peristiwa terjadinya gerhana bulan dan matahari.

Secara keseluruhan, cakupan materi Astronomi SD/MI pada kurikulum 2013 lebih sedikit dibandingkan kurikulum 2006. Demikian juga untuk target siswa, materi astronomi untuk kurikulum 2013 hanya diberikan untuk kelas VI saja. Namun demikian, hal ini tidak mempersempit/mengurangi materi al-Qur'an yang berkaitan dengan astronomi untuk diberikan kepada siswa, dibandingkan dengan materi pada kurikulum 2006. Artinya semua ayat al-Quran yang berhubungan 
dengan astronomi seperti pada materi kurikulum 2006 dapat diberikan untuk materi astronomi sesuai kurikulum 2013.

\section{F. Terbentuknya Alam Semesta}

The Big Bang adalah fenomena tentang terbentuknya alam semesta yang dijelaskan oleh ahli fisika astronomi (astrophysicists). Teori ini didukung oleh data hasil observasi dan experiment oleh astronomer dan astrophysicist selama puluhan tahun. Menurut the Big bang, seluruh alam semesta awalnya adalah sebuah massa yang sangat besar (primary nebula). Kemudian terjadilah sebuah ledakan besar 'big bang' (secondary separation) yang membentuk galaksi. Kemudian dalam galaksi terbentuk bintang, planet, matahari, bulan, dan benda angkasa lainnya. ${ }^{7}$

Ayat Al-Qur'an yang mengandung berita tentang pembentukan alam semesta adalah: 1. QS Al-An'aam (6): 101. Yang berarti: “Dialah pencipta langit dan Bumi”; 2. QS Al-Anbiyaa (21): 30. Yang berarti: “ Dan apakah orang-orang yang kafir tidak mengetahui bahwasannya langit dan bumi itu keduanya dahulu adalah yang padu, kemudian Kami pisahkan antara keduanya. Dan dari air Kami jadikan sesuatu yang hidup. Maka mengapakah mereka tiada juga beriman?”; 3. QS Fushshilat (41): 11: "Kemudian Dia menuju langit dan langit itu masih merupakan asap, lalu Dia berkata kepadanya dan kepada bumi: "Datanglah kamu keduanya menurut perintahKu dengan suka hati atau terpaksa". Keduanya menjawab: "Kami datang dengan suka hati".

Keterangan yang diberikan Al-Qur'an ini sesuai dengan penemuan ilmu pengetahuan tentang kejadian alam semesta. Para ilmuwan menyepakati bahwa sebelum galaksi terbentuk, materi angkasa berupa bentuk 'gas'. Singkatnya materi/awan gas raksasa telah ada sebelum terbentuknya galaksi. Dalam menjelaskan materi angkasa ini, kata 'smoke'/asap lebih tepat daripada 'gas'.

${ }^{7}$ Zakir Na'ik, The Qur'an and Modern Science; Compatibel or Incompatible. 
Tabel 1. Analisis Materi Astronomi

\begin{tabular}{|c|c|c|c|}
\hline Kelas & $\begin{array}{c}\text { Kompetensi } \\
\text { Dasar }\end{array}$ & Materi Sains & Ayat al-Quran yang Berkaitan \\
\hline I & $\begin{array}{ll}5.1 & \begin{array}{l}\text { Mengenal } \\
\text { berbagai }\end{array} \\
\text { benda langit } \\
\text { melalui } \\
\text { pengamatan }\end{array}$ & $\begin{array}{l}\text { - } \text { Matahari } \\
\text { terbit di } \\
\text { sebelah timur } \\
\text { - Matahari } \\
\text { memancarkan } \\
\text { sinar } \\
\text { - Sinar matahari } \\
\text { terang } \\
\text { benderang } \\
\text { - } \text { matahari } \\
\text { terbenam pada } \\
\text { sore hari di } \\
\text { sebelah barat } \\
\text { - Matahari } \\
\text { adalah benda } \\
\text { langit } \\
\text { - Matahari } \\
\text { terlihat dari } \\
\text { pagi hingga } \\
\text { sore hari } \\
\text { - Awan, } \\
\text { burung, } \\
\text { pesawat } \\
\text { berada di } \\
\text { langit tapi } \\
\text { bukan benda } \\
\text { langit } \\
\text { - Pada waktu } \\
\text { malam } \\
\text { matahari tidak } \\
\text { terlihat } \\
\text { - Pada malam } \\
\text { hari di langit } \\
\text { ada bulan dan } \\
\text { bintang } \\
\text { Bulan dan } \\
\text { bintang adalah }\end{array}$ & $\begin{array}{l}\text { - Terjadinya siang dan } \\
\text { malam: } \\
\text { QS Az Zumar (39:5): “Dia } \\
\text { menciptakan langit dan bumi } \\
\text { dengan (tujuan) yang benar. } \\
\text { Dia menutupkan malam atas } \\
\text { siang dan menutupkan siang } \\
\text { atas malam ...”. } \\
\text { - Matahari memancarkan } \\
\text { cahaya sendiri sedang } \\
\text { bulan hanya memantulkan } \\
\text { cahaya dari matahari: } \\
\text { QS Al FurQon (61): “Maha } \\
\text { suci Allah yang menjadikan } \\
\text { di langit gugusan-gugusan } \\
\text { bintang dan Dia menjadikan } \\
\text { juga padanya lampu dan } \\
\text { bulan yang memberi } \\
\text { cahaya." } \\
\text { Benda-benda Langit } \\
\text { (Bintang Memancarkan } \\
\text { Cahaya Sendiri): QS Ash- } \\
\text { Shaffat [37] : 6 difirmankan, } \\
\text { "Sesungguhnya Kami telah } \\
\text { menghiasi langit yang } \\
\text { terdekat dengan hiasan } \\
\text { bintang-bintang.”, QS } \\
\text { Fushshilat [41]: 12 } \\
\text { difirmankan, “... dan Kami } \\
\text { hiasi langit yang dekat } \\
\text { dengan bintang-bintang yang } \\
\text { cemerlang ....” }\end{array}$ \\
\hline
\end{tabular}




\begin{tabular}{|c|c|c|c|}
\hline Kelas & $\begin{array}{c}\text { Kompetensi } \\
\text { Dasar }\end{array}$ & Materi Sains & Ayat al-Quran yang Berkaitan \\
\hline & & 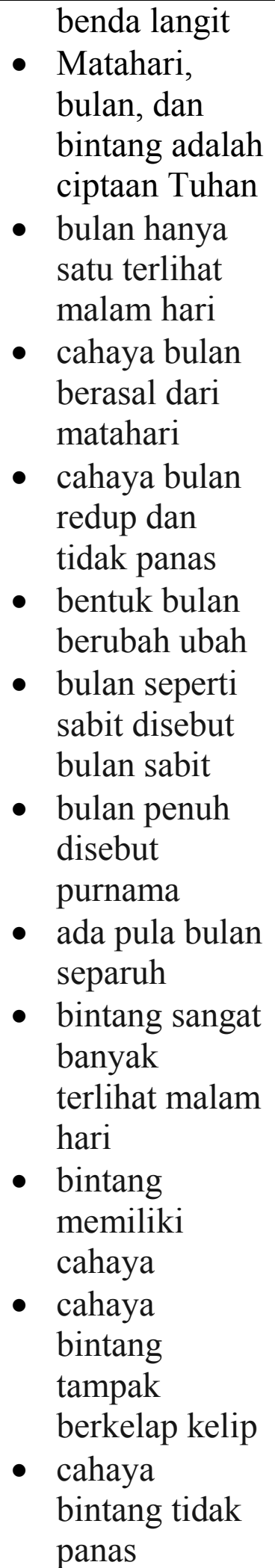 & \\
\hline
\end{tabular}




\begin{tabular}{|c|c|c|c|}
\hline Kelas & $\begin{array}{c}\text { Kompetensi } \\
\text { Dasar }\end{array}$ & Materi Sains & Ayat al-Quran yang Berkaitan \\
\hline II & $\begin{array}{ll}4.1 & \\
& \text { Mengidentifi } \\
\text { kasi } & \\
\text { kenampakan } \\
\text { matahari pada } \\
\text { pagi, siang } \\
\text { dan sore hari }\end{array}$ & $\begin{array}{l}\text { - } \text { matahari } \\
\text { bergerak dari } \\
\text { timur ke barat } \\
\text { - pagi hari } \\
\text { matahari terbit } \\
\text { di sebelah } \\
\text { timur kira kira } \\
\text { pukul } \\
\text { setengah } \\
\text { enam pagi } \\
\text { - tengah hari } \\
\text { pukul dua } \\
\text { belas siang } \\
\text { matahari } \\
\text { berada tepat } \\
\text { di atas kepala } \\
\text { - sore hari } \\
\text { matahari } \\
\text { terbenam di } \\
\text { sebelah barat } \\
\text { - kira-kira } \\
\text { pukul enam } \\
\text { sore } \\
\text { - matahari } \\
\text { terbenam } \\
\text { tanda malam } \\
\text { tiba } \\
\text { - sinar matahari } \\
\text { pagi hari sinar } \\
\text { matahari } \\
\text { terasa hangat } \\
\text { - semakin siang } \\
\text { sinarnya } \\
\text { semakin panas } \\
\text { semakin sore } \\
\text { sinar matahari } \\
\text { semakin redup } \\
\text { dan panasnya }\end{array}$ & $\begin{array}{l}\text { - Terjadinya siang dan } \\
\text { malam: } \\
\text { QS al Anbiya (33): "Dan } \\
\text { dialah telah } \\
\text { menciptakan malam dan } \\
\text { siang, matahari dan bulan. } \\
\text { Masing-masing dari } \\
\text { keduanya itu beredar dalam } \\
\text { falaknya. } \\
\text { QS Yaasiin (40): “dan bukan } \\
\text { matahari mendahului bulan } \\
\text { dan bukan juga malam } \\
\text { mendahului siang. Mereka } \\
\text { beredar dalam falak sendiri.” } \\
\text { Atap yang terpelihara } \\
\text { (atmosfer) } \\
\text { QS Al-Anbiyaa' (21): 32: } \\
\text { "Dan Kami menjadikan } \\
\text { langit itu sebagai atap yang } \\
\text { terpelihara, sedangmereka } \\
\text { berpaling dari segala tanta- } \\
\text { tanda (kekuasaan Allah) yang } \\
\text { ada padanya”. } \\
\text { QS Ath-Thaariq (86): 11: “ } \\
\text { Demi langit yang } \\
\text { mengandung/mengembalikan } \\
\text { hujan” }\end{array}$ \\
\hline
\end{tabular}




\begin{tabular}{|c|c|c|c|}
\hline Kelas & $\begin{array}{c}\text { Kompetensi } \\
\text { Dasar }\end{array}$ & Materi Sains & Ayat al-Quran yang Berkaitan \\
\hline & & $\begin{array}{ll}\text { berkurang } \\
\text { - } \text { bayangan oleh } \\
\text { sinar matahari } \\
\text { saat matahari } \\
\text { di timur } \\
\text { bayangan } \\
\text { berada di } \\
\text { sebelah barat } \\
\text { - tengah hari } \\
\text { bayangan } \\
\text { tepat di } \\
\text { tengah tengah } \\
\text { - saat matahari } \\
\text { di barat } \\
\text { bayangan } \\
\text { berada di } \\
\text { sebelah timur }\end{array}$ & \\
\hline IV & $\begin{array}{ll}9.1 & \\
& \begin{array}{l}\text { Mendeskripsi } \\
\text { kan }\end{array} \\
& \text { perubahan } \\
& \text { kenampakan } \\
& \text { bumi } \\
9.2 & \\
& \text { Mendeskripsi } \\
& \text { kan posisi } \\
& \text { bulan dan } \\
& \text { kenampakan } \\
& \text { bumi dari hari } \\
\text { ke hari }\end{array}$ & $\begin{array}{l}\text { - Perputaran } \\
\text { bumi } \\
\text { mengelilingi } \\
\text { matahari } \\
\text { dapat } \\
\text { menyebabkan } \\
\text { perubahan } \\
\text { siang dan } \\
\text { malam di } \\
\text { bumi. } \\
\text { - Perubahan } \\
\text { penampakan } \\
\text { bumi } \\
\text { disebabkan } \\
\text { pasang surut } \\
\text { air laut, erosi, } \\
\text { badai, dan } \\
\text { kebakaran. } \\
\text { Matahari } \\
\text { merupakan } \\
\text { bintang yang } \\
\text { paling dekat }\end{array}$ & $\begin{array}{l}\text { - Terjadinya siang dan } \\
\text { malam: } \\
\text { QS al Anbiya (33): "Dan } \\
\text { dialah telah } \\
\text { menciptakan malam dan } \\
\text { siang, matahari dan bulan. } \\
\text { Masing-masing dari } \\
\text { keduanya itu beredar dalam } \\
\text { falaknya. } \\
\text { Bentuk bumi } \\
\text { QS Luqman (31:29) tentang } \\
\text { siang dan malam: "Tidaklah } \\
\text { kamu memperhatikan, bahwa } \\
\text { sesungguhnya } \\
\text { memasukkan malam ke } \\
\text { dalam siah } \\
\text { memasukkan siang ke dalam } \\
\text { malam...." } \\
\text { QS Az Zumar (39:5): "Dia } \\
\text { menciptakan langit dan bumi } \\
\text { dengan (tujuan) yang benar. } \\
\text { Dia menutupkan malam atas }\end{array}$ \\
\hline
\end{tabular}




\begin{tabular}{|c|c|c|c|}
\hline Kelas & $\begin{array}{c}\text { Kompetensi } \\
\text { Dasar }\end{array}$ & Materi Sains & Ayat al-Quran yang Berkaitan \\
\hline & & $\begin{array}{l}\text { dengan bumi, } \\
\text { sehingga } \\
\text { tampak besar } \\
\text { dibandingkan } \\
\text { dengan } \\
\text { bintang yang } \\
\text { lain. } \\
\text { Bulan } \\
\text { bukanlah } \\
\text { bintang } \\
\text { karena tidak } \\
\text { memancarkan } \\
\text { cahaya sendiri } \\
\text { (hanya } \\
\text { memantulkan } \\
\text { cahaya } \\
\text { matahari). } \\
\text { Perubahan } \\
\text { posisi antara } \\
\text { matahari, } \\
\text { bulan, dan } \\
\text { bumi } \\
\text { menyebabkan } \\
\text { bentuk bulan } \\
\text { yang tampak } \\
\text { dari bumi. } \\
\text { bentuk bulan } \\
\text { disebut fase } \\
\text { bulan, yang } \\
\text { meliputi fase } \\
\text { bulan baru, } \\
\text { bulan sabit, } \\
\text { bulan separuh, } \\
\text { bulan } \\
\text { bungkuk, dan } \\
\text { bulan } \\
\text { purnama. } \\
\text { beruan }\end{array}$ & $\begin{array}{l}\text { siang dan menutupkan siang } \\
\text { atas malam ...". }\end{array}$ \\
\hline VI & 9.1 & - Tata surya & - Terbentuknya Alam \\
\hline
\end{tabular}

Jurnal Pendidikan Agama Islam Volume 01 Nomor 01 Mei 2013 Hal 152 - 160 


\begin{tabular}{|c|c|c|c|c|}
\hline Kelas & & $\begin{array}{l}\text { Kompetensi } \\
\text { Dasar }\end{array}$ & Materi Sains & Ayat al-Quran yang Berkaitan \\
\hline & 9.2 & \begin{tabular}{l}
\multicolumn{1}{c}{ Mendeskri } \\
psikan sistem \\
tata surya dan \\
posisi \\
penyusun tata \\
surya \\
$\quad$ Mendeskri \\
psikan \\
peristiwa \\
rotasi bumi, \\
revolusi bumi \\
dan revolusi \\
bulan \\
Menjelaskan \\
terjadinya \\
gerhana bulan \\
dan gerhana \\
matahari \\
Menjelaskan \\
perhitungan \\
kalender \\
Masehi dan \\
kalender \\
Hijriah
\end{tabular} & $\begin{array}{l}\text { adalah } \\
\text { susunan benda } \\
\text { angkasa yang } \\
\text { terdiri atas } \\
\text { Matahari dan } \\
\text { planet yang } \\
\text { mengelilingin } \\
\text { ya. } \\
\text { - Planet-planet } \\
\text { dalam tata } \\
\text { surya adalah } \\
\text { Merkurius, } \\
\text { Venus, Bumi, } \\
\text { Mars, Yupiter, } \\
\text { - Saturnus, } \\
\text { Uranus, dan } \\
\text { Neptunus. } \\
\text { Planet yang } \\
\text { letaknya } \\
\text { paling jauh } \\
\text { dari Matahari } \\
\text { adalah } \\
\text { Neptunus. } \\
\text { Planet yang } \\
\text { paling dekat } \\
\text { dari matahari } \\
\text { adalah } \\
\text { Merkurius. } \\
\text { Kelompok } \\
\text { planet dibagi } \\
\text { menjadi dua, } \\
\text { yaitu planet } \\
\text { dalam dan } \\
\text { planet luar. } \\
\text { Planet dalam } \\
\text { terdiri atas } \\
\text { Merkurius dan } \\
\text { Venus. Planet } \\
\text { luar terdiri }\end{array}$ & $\begin{array}{l}\text { Semesta } \\
\text { QS Al-An'aam (6): 101.“ } \\
\text { Dialah pencipta langit dan } \\
\text { Bumi” } \\
\text { QS Al-Anbiyaa (21): 30. “ } \\
\text { Dan apakah orang-orang } \\
\text { yang kafir tidak mengetahui } \\
\text { bahwasannya langit dan bumi } \\
\text { itu keduanya dahulu adalah } \\
\text { yang padu, kemudian Kami } \\
\text { pisahkan antara keduanya. } \\
\text { Dan dari air Kami jadikan } \\
\text { sesuatu yang hidup. Maka } \\
\text { mengapakah mereka tiada } \\
\text { juga beriman?” } \\
\text { QS Fushshilat (41): 11: “ } \\
\text { Kemudian Dia menuju langit } \\
\text { dan langit itu masih } \\
\text { merupakan asap, lalu Dia } \\
\text { berkata kepadanya dan } \\
\text { kepada bumi: "Datanglah } \\
\text { kamu keduanya menurut } \\
\text { perintahKu dengan suka hati } \\
\text { atau terpaksa”. Keduanya } \\
\text { menjawab: "Kami datang } \\
\text { dengan suka hati”. } \\
\text { Benda langit mempunyai } \\
\text { orbit masing-masing } \\
\text { QS Al-Anbiyaa' (21): 33: } \\
\text { dan Allah-lah yang } \\
\text { menciptakan siang dan } \\
\text { malam, dan matahari dan } \\
\text { bulan. Masing-masing dari } \\
\text { keduanya itu beredar dalam } \\
\text { garis edarnya. } \\
\text { QS Yasiin (36): 40: Tidaklah } \\
\text { mungkin bagi matahari } \\
\text { mendapatkan bulan dan } \\
\text { malampun tidak dapat }\end{array}$ \\
\hline
\end{tabular}




\begin{tabular}{|c|c|c|c|}
\hline Kelas & $\begin{array}{c}\text { Kompetensi } \\
\text { Dasar }\end{array}$ & Materi Sains & Ayat al-Quran yang Berkaitan \\
\hline & & $\begin{array}{l}\text { atas Mars, } \\
\text { Yupiter, } \\
\text { Saturnus, } \\
\text { Uranus, dan } \\
\text { Neptunus. } \\
\text { - Planet } \\
\text { terbesar dalam } \\
\text { tata surya kita } \\
\text { adalah } \\
\text { Yupiter. } \\
\text { Komet disebut } \\
\text { juga bintang } \\
\text { berekor. } \\
\text { Komet } \\
\text { merupakan } \\
\text { benda langit } \\
\text { yang } \\
\text { mengelilingi } \\
\text { Matahari } \\
\text { dengan orbit } \\
\text { yang sangat } \\
\text { lonjong. } \\
\text { Meteor adalah } \\
\text { benda langit } \\
\text { yang } \\
\text { meteorid yang } \\
\text { planet. Satelit } \\
\text { ditarik oleh } \\
\text { planet akibat } \\
\text { gaya gravitasi. } \\
\text { Meteor } \\
\text { bergesekan } \\
\text { dengan } \\
\text { atmosfer } \\
\text { planet } \\
\text { sehingga } \\
\text { berpijar. } \\
\text { - }\end{array}$ & $\begin{array}{l}\text { mendahului siang. Dan } \\
\text { masing-masing beredar pada } \\
\text { garis edarnya. } \\
\text { - Matahari akan padam } \\
\text { At-Takwir [81], ayat } 1 \\
\text { "Apabila matahari digulung } \\
\text { dan apabila bintang-bintang } \\
\text { berjatuhan." } \\
\text { QS Yasiin (36): 37, “ Dan } \\
\text { suatu tanda (kekuasaan Allah } \\
\text { yang besar) bagi mereka } \\
\text { adalah malam; Kami } \\
\text { tanggalkan siang dari malam } \\
\text { itu, maka dengan serta merta } \\
\text { mereka berada dalam } \\
\text { kegelapan." }\end{array}$ \\
\hline
\end{tabular}




\begin{tabular}{|c|c|c|c|}
\hline Kelas & $\begin{array}{c}\text { Kompetensi } \\
\text { Dasar }\end{array}$ & Materi Sains & Ayat al-Quran yang Berkaitan \\
\hline & & $\begin{array}{l}\text { alami Bumi } \\
\text { adalah Bulan. } \\
\text { - Selain } \\
\text { berevolusi } \\
\text { mengelilingi } \\
\text { Matahari, } \\
\text { Bumi juga } \\
\text { berotasi } \\
\text { (berputar pada } \\
\text { porosnya). } \\
\text { - Pengaruh dari } \\
\text { rotasi Bumi } \\
\text { adalah } \\
\text { terjadinya } \\
\text { siang dan } \\
\text { malam. Selain } \\
\text { itu, rotasi } \\
\text { Bumi } \\
\text { memengaruhi } \\
\text { gerak semu } \\
\text { harian } \\
\text { Matahari serta } \\
\text { pembagian } \\
\text { waktu. } \\
\text { Pengaruh } \\
\text { revolusi Bumi } \\
\text { adalah } \\
\text { terjadinya } \\
\text { perbedaan } \\
\text { musim. } \\
\text { Bulan } \\
\text { berotasi, } \\
\text { berevolusi } \\
\text { mengelilingi } \\
\text { Bumi, dan } \\
\text { bersama-sama } \\
\text { Bumi } \\
\text { mengelilingi } \\
\text { Matahari. }\end{array}$ & \\
\hline
\end{tabular}




\begin{tabular}{|c|c|c|c|}
\hline Kelas & $\begin{array}{c}\text { Kompetensi } \\
\text { Dasar }\end{array}$ & Materi Sains & Ayat al-Quran yang Berkaitan \\
\hline & & $\begin{array}{l}\text { Pengaruh } \\
\text { revolusi bulan } \\
\text { adl terjadinya } \\
\text { perubahan } \\
\text { bentuk Bulan. } \\
\text { - Gerhana bulan } \\
\text { terjadi jika } \\
\text { kedudukan } \\
\text { Matahari, } \\
\text { Bumi, dan } \\
\text { Bulan terletak } \\
\text { satu garis. } \\
\text { Bumi berada } \\
\text { di antara } \\
\text { Bulan dan } \\
\text { Matahari. } \\
\text { Gerhana } \\
\text { Matahari } \\
\text { terjadi jika } \\
\text { kedudukan } \\
\text { Matahari, } \\
\text { Bulan, dan } \\
\text { Bumi berada } \\
\text { dalam satu } \\
\text { garis. Bulan } \\
\text { berada di } \\
\text { antara } \\
\text { Matahari dan } \\
\text { Bumi. } \\
\text { Revolusi } \\
\text { Bumi } \\
\text { digunakan } \\
\text { sebagai dasar } \\
\text { pembuatan } \\
\text { kalender } \\
\text { Masehi. } \\
\text { Revolusi } \\
\text { Bulan } \\
\text { digunakan }\end{array}$ & \\
\hline
\end{tabular}

Jurnal Pendidikan Agama Islam Volume 01 Nomor 01 Mei 2013 Hal 156 - 160 


\begin{tabular}{|c|c|l|l|}
\hline Kelas & $\begin{array}{c}\text { Kompetensi } \\
\text { Dasar }\end{array}$ & Materi Sains & Ayat al-Quran yang Berkaitan \\
\hline & & sebagai dasar & \\
& & pembuatan & \\
& & kalender & \\
& & Hijriah. & \\
\hline
\end{tabular}

\section{G. Mengembangnya Alam Semesta}

Sejak terjadinya peristiwa "Big Bang", alam semesta telah mengembang secara terus menerus dengan kecepatan maha dasyat. Para ilmuwan menyamakan peristiwa mengembangknya alam semesta dengan permukaan balon yang sedang ditiup. Perhitungan, penelitian, pengamatan dan perhitungan yang dilakukan dengan teknologi modern, mengungkapkan bahwa alam semesta sesungguhnya memiliki permulaan dan ia terus menerus mengembang. Sebelumnya, sampai awal abad 20 terdapat pandangan umum bahwa alam semesta bersifat tetap.

Dalam al-Qur'an yang diturunkan 14 abad yang lalu, telah digambarkan tentang pengembangan alam semesta, yaitu pada: QS (51: 47): " Dan langit itu Kami bangun dengan kekuasaan Kami dan sesungguhnya Kami benar-benar meluaskannya." kata langit digunakan untuk menyebut alam semesta. Dalam ayat ini digambarkan bahwa alam semesta mengalami perluasan dan mengembang. ${ }^{8}$

\section{H. Strategi Penyampaian Ayat Al-Quran dalam Pembelajaran Sains}

Berbagai strategi pembelajaran dapat digunakan untuk menyampaikan ayat al-Quran, sehingga dapat diterima dan dicerna oleh para siswa. Tujuan penyampaian ayat al-Quran beserta tafsirnya ini dimaksudkan agar anak dapat memiliki pemahaman bahwa ilmu dalam al-Quran sangatlah luas dan mendukung temuan-temuan ilmiah. Selain bertujuan agar siswa semakin yakin akan kebenaran al-Qur'an, kegiatan ini juga bertujuan agar siswa terpacu untuk mempelajari al-Quran lebih

\footnotetext{
${ }^{8}$ Wenny Wulandari, et al, Mengaji Keilmiahan Ayat-ayat Sains dalam Al-Qur'an terhadap Ilmu Pengetahuan Modern, Makalah Studi Islam Universitas Ahmad Dahlan Yogyakarta.
} 
lanjut, tidak hanya ayat yang disampaiakan guru. Dengan mempelajari lebih lanjut apa yang ada dalam al-Qur'an diharapkan siswa akan belajar lebih giat untuk dapat melakukan pembuktian-pembuktian secara ilmiah ilmu-ilmu yang terkandung di al-Quran.

Pengintegrasian ayat al-Quran pada materi sains memerlukan strategi yang berbeda dengan konsep ilmu tunggal. Dalam konteks integrasi, penyampaian ayat al-Qur'an ini dapat dipandang dari dua sisi, pertama konsep ayat al-Qur'an dianggap sebagai bagian dari konsep yang sama dengan ilmu sains itu sendiri. Kedua, ayat al-Qur'an dianggap sebagai konsep yang berbeda dengan konsep sains yang dijelaskan. Untuk pandangan pertama (integrasi konsep sejenis) dapat mengaplikasikan model connected. Dan pandangan kedua dapat mengaplikasikan model integrated. Kedua model ini dapat divariasikan satu sama lain sehingga akhirnya diperoleh aplikasi strategi yang sesuai untuk diapliaksikan dengan variabel-variabel lain dalam pembelajaran (kondisi siswa, ketersediaan media/material, dan lain-lain).

Pengintegrasian ayat al-Quran pada materi astronomi sebatas bertujuan pada aspek knowing/pengetahuan. Dalam aspek pengetahuan, murid memiliki pengetahuan mengenai berbagai hal yang berkenaan dengan pemahaman kandungan Al-Qur'an. Untuk mencapai tujuan ini, guru dapat memilih metode ceramah, tanya jawab, dan demonstrasi. Beberapa metode tersebut mengarah pada direct instruction.

Penyampaian ayat ini diharapkan merupakan bagian inti dari pembelajaran, meskipun bukan yang utama. Yang utama dalam penanaman konsep sains yang berkaitan. Meskipun bukan yang utama tetapi tetap masuk kegiatan inti yang harus dilakukan konfirmasi terhadapnya. Penyampaian ayat ini dapat dimasukkan dalam kegiatan konfirmasi, sehingga lebih tepat kalau digunakan metode direct instruction (pembelajaran langsung). Selain hanya memerlukan waktu yang singkat, dengan direct instruction, siswa mempunyai pemahaman yang sama tentang makna yang disampaikan. Untuk itu guru harus terlebih dahulu memahami dengan sebaik-baiknya apa yang akan dikonfirmasikan ke siswa.

Direct instruction dapat divariasi dengan penggunaan strategi yang menarik, misalnya penggunaan media yang menarik seperti penggunaan video pembelajaran, reading aloud, dan hafalan. 
1. Dengan video pembelajaran. Sudah banyak beredar video-video tentang fenomena alam semesta yang dikaitkan dengan al-Quran. Guru dapat memutar video tersebut dan memberi penjelasan atasa apa yang ada di video. Dengan strategi ini, guru dapat terbantu dalam menyampaiakan konfirmasinya sehingga apa yang disampaiakan benar adanya.

2. Reading aloud. Dengan membaca, siswa akan dapat mengeksplore kemampuannya masing-masing untuk memahami ayat-ayat terkait materi astronomi. Reading aloud dapat dilanjutkan dengan menghafal ayat yang berkaitan.

3. Hafalan. Anak diminta menghafal satu ayat dan terjemahannya untuk ditunjukkan ke guru minggu berikutnya. Kegiatan ini dapat diintegrasikan dengan pelajaran lain seperti materi hafalan ayat.

\section{Kesimpulan}

Materi astronomi di SD/MI diberikan di kelas I, II, dan VI, yang meliputi materi pengenalan benda-benda langit, terjadinya siang dan malam, posisi bulan, sistem tata surya, rotasi, revolusi, gerhana bulan dan matahari, serta perhitungan kalender masehi dan hijriyah. Ayat al-Qur'an terkait materi astronomi SD adalah: QS Az Zumar (39:5), QS Al FurQon (61), QS Ash-Shaffat [37] : 6, QS Fushshilat [41]: 12, QS al Anbiya (33): QS Yaasiin (40), QS Ath-Thaariq (86): 11, QS Luqman (31:29), QS Az Zumar (39:5), QS Al-An'aam (6): 10, QS Al-Anbiyaa (21): 30, QS Fushshilat (41): 11, At-Takwir [81]: 1, QS Yasiin (36): 37.

Pembelajaran ayat yang dipadukan dengan penyampaian konsep sains mengarah pada tujuan aspek knowing. Kosekuensinya lebih tepat kalau menggunakan model pembelajaran langsung (direct instruction). Model terpadu yang dapat diaplikasikan adalah model connected (keterhubungan), yang menghubungkan antar beberapa konsep dalam satu mata pelajaran, maupun model integrated (keterpaduan), yang menghubungkan antar bidang studi.

Hasil kajian ini dapat digunakan oleh para guru sains dalam mengimplementasikan pembelajran sains terutama astronomi dengan penguatan pemberian ayat-ayat al-Qura'an beserta tafsirnya. Selain 
memperkuat konsep sains itu sendiri, siswa juga secara langsung akan semakin mengimani al-Qur'an sebagai sumber dari segala ilmu.

\section{DAFTAR PUSTAKA}

Al-Qur'an dan Terjemahannya

Dirjen Diktis, Pembelajaran Al-Quran dan Hadis (Pembelajaran Memahami

Kandungan Al-Qur'an dan Hadist) (Jakarta: Direktorat Jendral Pendidikan Islam. 2010).

Jamiludin. Integrasi Pendidikan Islami: Nilai-nilai Islami dalam Pembelajaran.

Mohd Yakub Zulkifli and majid Daneshgar, Islam and the relation of science. Presnted paper on 2011 International Conference on Humanities, Society and Culture, IPEDR Vol.20 (2011). Siangapore: IACSIT Press.

Nanang Gojali, Manusia, Pendidikan, dan Sains dalam Perspektif Tafsir Hermeneutic (Jakarta: Rineka Cipta, 2004).

Zakir Na'ik. Qur'an and Modern Science; Compatibel or Incompatible. (Riyadh: Dar-US-Salaam, 2007)

Wenny Wulandari, et al, Mengaji Keilmiahan Ayat-ayat Sains dalam AlQur'an terhadap Ilmu Pengetahuan Modern. Makalah Studi Islam Universitas Ahmad Dahlan Yogyakarta. 